\title{
Perceptions and Needs of Artificial Intelligence in Health Care to Increase Adoption: Scoping Review
}

\author{
Han Shi Jocelyn Chew ${ }^{1}$, DPhil; Palakorn Achananuparp ${ }^{2}$, DPhil \\ ${ }^{1}$ Alice Lee Centre for Nursing Studies, Yong Loo Lin School of Medicine, National University of Singapore, Singapore, Singapore \\ ${ }^{2}$ Living Analytics Research Centre, Singapore Management University, Singapore, Singapore
}

\section{Corresponding Author:}

Han Shi Jocelyn Chew, DPhil

Alice Lee Centre for Nursing Studies

Yong Loo Lin School of Medicine

National University of Singapore

Level 3, Clinical Research Centre

Block MD11, 10 Medical Drive

Singapore, 117597

Singapore

Phone: 6565168687

Email: jocelyn.chew.hs@nus.edu.sg

\section{Abstract}

Background: Artificial intelligence (AI) has the potential to improve the efficiency and effectiveness of health care service delivery. However, the perceptions and needs of such systems remain elusive, hindering efforts to promote AI adoption in health care.

Objective: This study aims to provide an overview of the perceptions and needs of AI to increase its adoption in health care.

Methods: A systematic scoping review was conducted according to the 5-stage framework by Arksey and O'Malley. Articles that described the perceptions and needs of AI in health care were searched across nine databases: ACM Library, CINAHL, Cochrane Central, Embase, IEEE Xplore, PsycINFO, PubMed, Scopus, and Web of Science for studies that were published from inception until June 21, 2021. Articles that were not specific to AI, not research studies, and not written in English were omitted.

Results: Of the 3666 articles retrieved, $26(0.71 \%)$ were eligible and included in this review. The mean age of the participants ranged from 30 to 72.6 years, the proportion of men ranged from $0 \%$ to $73.4 \%$, and the sample sizes for primary studies ranged from 11 to 2780. The perceptions and needs of various populations in the use of AI were identified for general, primary, and community health care; chronic diseases self-management and self-diagnosis; mental health; and diagnostic procedures. The use of AI was perceived to be positive because of its availability, ease of use, and potential to improve efficiency and reduce the cost of health care service delivery. However, concerns were raised regarding the lack of trust in data privacy, patient safety, technological maturity, and the possibility of full automation. Suggestions for improving the adoption of AI in health care were highlighted: enhancing personalization and customizability; enhancing empathy and personification of AI-enabled chatbots and avatars; enhancing user experience, design, and interconnectedness with other devices; and educating the public on AI capabilities. Several corresponding mitigation strategies were also identified in this study.

Conclusions: The perceptions and needs of $\mathrm{AI}$ in its use in health care are crucial in improving its adoption by various stakeholders. Future studies and implementations should consider the points highlighted in this study to enhance the acceptability and adoption of AI in health care. This would facilitate an increase in the effectiveness and efficiency of health care service delivery to improve patient outcomes and satisfaction.

(J Med Internet Res 2022;24(1):e32939) doi: 10.2196/32939

\section{KEYWORDS}

artificial intelligence; health care; service delivery; perceptions; needs; scoping; review 


\section{Introduction}

\section{Background}

Rapid advances in artificial intelligence (AI)—software systems designed to mimic human intelligence or cognitive functions-have sparked confidence in its potential to enhance the efficiency of health care service delivery and patient outcomes [1-3]. However, although AI has been rapidly adopted in many industries, such as finance and information technology (IT), its adoption in health care remains relatively lagged because of the ethical and safety considerations that are more pronounced when it comes to human lives at stake [4]. AI-powered systems in health care can autonomously or semiautonomously perform a wide variety of tasks, such as medical diagnosis [5], treatment [6], and self-monitoring and coaching $[7,8]$. In some studies, AI has been shown to outperform human capabilities, such as analyses of chest x-ray images by radiologists [9]. Not only is AI expected to improve the quality of care and health outcomes for patients by decreasing human errors, but it is also likely to free up time for clinicians and health care workers from routine and repetitive tasks, enabling them to focus on more complex tasks $[9,10]$. For instance, in many areas of medical imaging, the use of fast and accurate AI-assisted diagnoses would significantly increase the workflow efficiency by processing more than 250 million images per day [11]. Various AI chatbots have also been developed to provide mental health counseling and assist overburdened clinicians [9]. Through AI-enabled apps and wearable devices, patients and the public could self-monitor and self-diagnose symptoms, such as atrial fibrillation, skin lesions, and retinal diseases [9].

Owing to the emerging nature of modern AI systems, the perceptions and needs of affected stakeholders (eg, health care providers, patients, caregivers, policy makers, and IT technicians) on the use of AI in health care are not yet fully understood. A large body of literature suggests that human factors, such as trust, perceived usefulness, and privacy, play an important role in the acceptance and adoption of past technologies in health care, including handheld devices [12], IT [13], and assistive technologies [14]. However, current evidence remains broad and general, and little is known about the perceptions and needs of AI in community health care. As the world makes a paradigm shift from curative to preventive medicine, AI holds a strong transformative potential to enhance sustainable health care by empowering self-care, such as self-monitoring and self-diagnosis. However, it is important to first understand the perspectives of all direct users of AI-driven systems (eg, patients and frontline health workers) and their perceived needs to ensure its successful adoption across different parts of the health care sector, especially community health care. Thus, this study aims to present an overview of the perceptions and needs of AI in community health care. The implications of this study will help inform the design of future health care-related AI technology to better fit the needs of users and enhance the adoption and acceptability of the technology.

\section{Definition of AI}

First, as the term $A I$ is broadly used in many disciplines to represent various forms of intelligent systems and algorithms, it is important to establish a concrete and unified definition of AI for this study. Specifically, we adopted the definition of AI proposed by the High-Level Expert Group on Artificial Intelligence [15], which describes AI in terms of both a technology and field of study:

\begin{abstract}
Artificial intelligence (AI) systems are software (and possibly also hardware) systems designed by humans that, given a complex goal, act in the physical or digital dimension by perceiving their environment through data acquisition, interpreting the collected structured or unstructured data, reasoning on the knowledge, or processing the information, derived from this data and deciding the best action(s) to take to achieve the given goal. AI systems can either use symbolic rules or learn a numeric model, and they can also adapt their behaviour by analysing how the environment is affected by their previous actions.

As a scientific discipline, AI includes several approaches and techniques, such as machine learning (of which deep learning and reinforcement learning are specific examples), machine reasoning (which includes planning, scheduling, knowledge representation and reasoning, search, and optimization), and robotics which includes control, perception, sensors, and actuators, as well as the integration of all other techniques into cyber-physical systems.
\end{abstract}

Furthermore, most, if not all, modern AI systems are considered artificial narrow intelligence (ANI) or Weak AI [15] designed to perform one or more specific tasks. In health care, domain-specific tasks for ANI may vary from performing human perceptions, such as image recognition [16] and natural language processing [17], to making complex clinical decisions, such as medical diagnostics [18]. Many recent advances and breakthroughs in ANI use learning-based approaches, namely, deep learning, in which computational models consisting of several layers of artificial neural networks (hence the titular deep) are trained by learning from a massive amount of sample data to perform specific tasks. Although recent performances of ANI appear very promising, ANI models are limited in their generalizability, that is, models trained to perform tasks in one domain cannot be generalized to other domains. For example, ANI trained to diagnose diabetic retinopathy from fundus images cannot be directly used to detect pneumonia from chest x-ray images. In contrast to ANI, artificial general intelligence (AGI) or Strong AI [15] belongs to a class of AI that displays true human intelligence, capable of continuously learning and performing any tasks like a real human. AGI is most likely in public consciousness when talking about $\mathrm{AI}$, as it is frequently portrayed in popular culture by sentient robots and self-aware systems. At present, no AI systems have been able to come close to exhibit the AGI capability. For a useful and concise summary regarding the definitions, terminologies, and history of AI, see the following technical reports: Ethics Guidelines for 
Trustworthy AI [15] and Historical Evolution of Artificial Intelligence [19].

\section{Methods}

A systematic scoping review was conducted according to the 5-stage framework by Arksey and O'Malley [20]. Results were reported according to the PRISMA (Preferred Reporting Items for Systematic Reviews and Meta-Analyses) checklist (Multimedia Appendix 1) [21].

\section{Stage 1: Identifying the Research Question}

Our research question was as follows: What is known about the perceptions and needs of AI in health care?

\section{Stage 2: Identifying Relevant Studies}

Studies were searched from inception until June 21, 2021, using a 3-step search strategy. First, potential keywords and Medical Subject Headings terms were generated through iterative searches on PubMed and Embase. Keywords such as machine learning did not result in better search outcomes (ie, many irrelevant results were retrieved, such as the use of machine learning to explore perceptions of other topics); hence, they were omitted. Next, keywords including artificial intelligence, AI; public; consumer; community; perception*; preference*; need ${ }^{*} ;$ opinions $*$; and acceptability were searched through nine databases: ACM Library, CINAHL, Cochrane Central, Embase, IEEE Xplore, PsycINFO, PubMed, Scopus, and Web of Science. Additional articles were also retrieved from the first 10 pages of the Google Scholar search results and the reference lists of the included full-text articles. The specific database searches combined with Boolean operators are detailed in Multimedia Appendix 2.

\section{Stage 3: Study Selection}

After removing duplicate articles, titles and abstracts were first screened by HSJC for inclusion eligibility. Articles were included if they were (1) focused on the use of AI in health care, except those focused on using AI to improve surgical techniques; (2) focused on perceptions, needs, and acceptability of AI in health care; (3) empirical studies or systematic reviews; (4) on adults aged $\geq 18$ years; and (5) used in a community setting.
Articles were excluded if they were (1) not specific to AI (eg, general eHealth or mobile health); (2) pilot studies, commentaries, perspectives, or opinion papers; and (3) not presented in the English language. In total, 43 full-text articles were screened independently by both coauthors, and discrepancies were resolved through discussions and consensus.

\section{Stage 4: Charting the Data}

Data were extracted by HSJC using Microsoft Excel according to the following headings: author, year, title, aim, type of publication, study design, country, AI applications in health care, data collection method, population characteristics, sample size, age (mean or range), proportion of men, acceptability, perceptions, needs and preferences, and limitations.

\section{Results}

\section{Stage 5: Collating, Summarizing, and Reporting Results}

A total of 3666 articles were retrieved from the initial search. After removing duplicate articles, 50.74\% (1860/3666) of titles and abstracts were screened, and $0.91 \%$ (17/1860) of full-text articles were excluded for reasons shown in Figure 1. A total of $1.4 \%(26 / 1860)$ of articles were included in this study, with the study characteristics summarized in Table 1 and detailed in Multimedia Appendix 3 [22-47]. The mean age of participants ranged from 30 to 72.6 years, and the proportion of men ranged from $0 \%$ to $73.4 \%$. Sample sizes for studies with human subject responses ranged from 11 to 2780, and secondary data (ie, journal articles and app reviews) ranged from 31 to 1826 [22-24]. Interestingly, 19\% (5/26) of studies focused on the use of chatbots in health care [23-27] and 31\% (8/26) of studies measured acceptability using questionnaires, surveys, interviews [25,26,28-33], and the discrete choice experiment (Multimedia Appendix 4 [22-32,34,36,37,39,41-44,47]) [34]. All the studies showed at least moderate acceptability, or $>50 \%$ of the participants showed acceptance toward the use of AI in health care, albeit only for minor conditions [26]. Age, IT skills, preference for talking to computers, perceived utility, positive attitude, and perceived trustworthiness were found to be associated with AI acceptability [25,26].

Figure 1. PRISMA (Preferred Reporting Item for Systematic Reviews and Meta-Analyses) flow diagram of search strategy. AI: artificial intelligence.

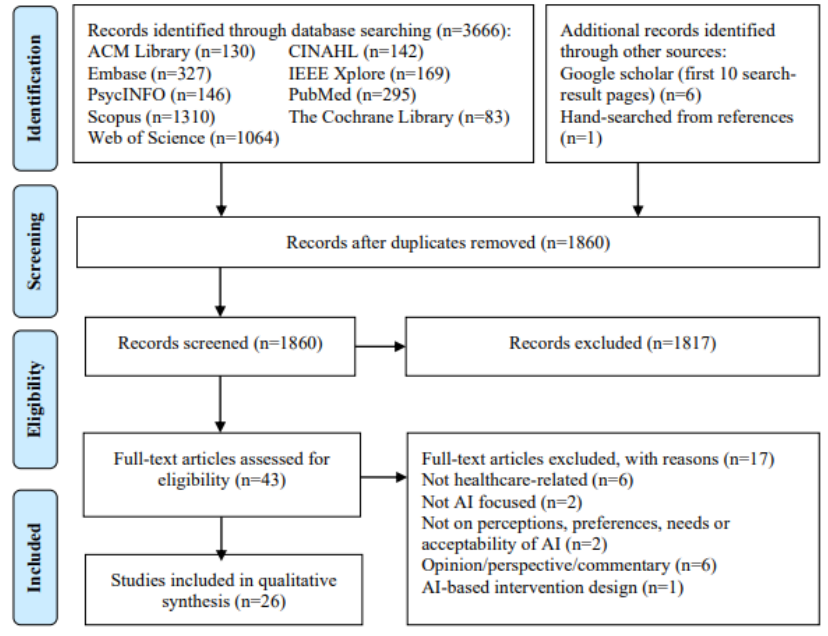


Table 1. Summary of study characteristics $(\mathrm{N}=26)$.

\begin{tabular}{|c|c|}
\hline Study characteristics & Value, $\mathrm{n}(\%)$ \\
\hline \multicolumn{2}{|l|}{ Country } \\
\hline Australia and New Zealand [35] & $1(4)$ \\
\hline Canada $[27,36-38]$ & $4(15)$ \\
\hline China $[22,32,33,39,40]$ & $6(23)$ \\
\hline France [41] & $1(4)$ \\
\hline India $[24,42]$ & $2(8)$ \\
\hline Korea [48] & $1(4)$ \\
\hline Saudi Arabia [29] & $1(4)$ \\
\hline Switzerland [30] & $1(4)$ \\
\hline United Kingdom $[23,26,31,43,44]$ & $5(19)$ \\
\hline United Kingdom, Cyprus, Australia, the Netherlands, Sweden, Spain, United States, and Canada [28] & $1(4)$ \\
\hline United States $[25,45,46]$ & $3(12)$ \\
\hline \multicolumn{2}{|l|}{ Type of publication } \\
\hline Journal papers $[22-29,31-41,43-47]$ & $24(92)$ \\
\hline Conference papers $[30,42]$ & $2(8)$ \\
\hline \multicolumn{2}{|l|}{ Study design } \\
\hline Observational $[22,24,27-30,33-35,39,43-47]$ & $15(58)$ \\
\hline Qualitative $[36-38,41,42]$ & $5(19)$ \\
\hline Mixed methods $[25,26,31,32,40]$ & $5(19)$ \\
\hline Systematic review [23] & $1(4)$ \\
\hline \multicolumn{2}{|l|}{ Population characteristics } \\
\hline General public $[22,24,26,30,32-34,37,45]$ & $9(35)$ \\
\hline Health care, government, technology, and industrial staff $[27-29,35,36,40-44]$ & $10(39)$ \\
\hline Patients and caregivers with specific diseases $[25,31,34,36,38,39,47]$ & $7(27)$ \\
\hline Mixture (systematic review) [23] & $1(4)$ \\
\hline \multicolumn{2}{|l|}{ Artificial intelligence applications in health care } \\
\hline General health care $[22,23,26,27,29,33,36,37,40,41,43]$ & $11(42)$ \\
\hline Primary [44] and community health care $[28,42]$ & $3(12)$ \\
\hline Chronic disease self-management $[25,31,47]$ & $3(12)$ \\
\hline Self-diagnosis $[30,32,34,39]$ & $4(15)$ \\
\hline Mental health $[24,38]$ & $2(8)$ \\
\hline Diagnostics $[35,45,46]$ & $3(12)$ \\
\hline
\end{tabular}

\section{Positive Perceptions}

\section{Overview}

Several positive perceptions on the use of AI in health care were highlighted in our findings (Table 2). 
Table 2. Perceptions on the use of artificial intelligence (AI) in health care.

\begin{tabular}{|c|c|c|c|c|c|c|c|}
\hline Study & $\begin{array}{l}\text { Available on } \\
\text { demand and us- } \\
\text { er-friendly }\end{array}$ & Efficiency & Price & $\begin{array}{l}\text { Lack of trust in } \\
\text { data privacy }\end{array}$ & $\begin{array}{l}\text { Lack of trust in } \\
\text { patient safety }\end{array}$ & $\begin{array}{l}\text { Lack of trust in } \\
\text { technology }\end{array}$ & $\begin{array}{l}\text { Concerns over } \\
\text { full automation }\end{array}$ \\
\hline $\begin{array}{l}\text { Abdi et al } \\
{[28]}\end{array}$ & $\begin{array}{l}\text { Able to collect } \\
\text { data nonintru- } \\
\text { sively }\end{array}$ & $\begin{array}{l}\text { Could support the } \\
\text { self-care needs of old- } \\
\text { er people-mobility, } \\
\text { self-care and domestic } \\
\text { life, social life and re- } \\
\text { lationships, psycholog- } \\
\text { ical support, and ac- } \\
\text { cess to health care; } \\
\text { potential uses for re- } \\
\text { mote monitoring and } \\
\text { prompting daily re- } \\
\text { minders, for example, } \\
\text { medications }\end{array}$ & $\begin{array}{l}\text { Cost was seen as } \\
\text { both a facilitator of } \\
\text { and a barrier to the } \\
\text { older people's } \\
\text { adoption of } \mathrm{AI}^{\mathrm{a}}\end{array}$ & $\begin{array}{l}\text { Especially in } \\
\text { voice-activated } \\
\text { devices }\end{array}$ & $\begin{array}{l}\text { Deemed techni- } \\
\text { cally and com- } \\
\text { mercially ready } \\
\text { to support the } \\
\text { care needs of } \\
\text { older people }\end{array}$ & $\mathrm{NS}^{\mathrm{b}}$ & NS \\
\hline $\begin{array}{l}\text { Abdullah } \\
\text { and Fakieh } \\
\text { [29] }\end{array}$ & NS & $\begin{array}{l}\text { Speeds up health care } \\
\text { processes }\end{array}$ & NS & NS & $\begin{array}{l}\text { AI was unable } \\
\text { to provide opin- } \\
\text { ions in unexpect- } \\
\text { ed situations }\end{array}$ & NS & $\begin{array}{l}\text { Most health } \\
\text { care employees } \\
\text { feared that the } \\
\text { AI would re- } \\
\text { place their job } \\
\text { (mean score } \\
3.11 \text { of } 4 \text { ) }\end{array}$ \\
\hline $\begin{array}{l}\text { Baldauf et al } \\
\text { [30] }\end{array}$ & $\begin{array}{l}\text { Constant avail- } \\
\text { ability, not re- } \\
\text { stricted by } \\
\text { physical loca- } \\
\text { tion }\end{array}$ & $\begin{array}{l}\text { Quicker diagnosis and } \\
\text { no waiting time }\end{array}$ & $\begin{array}{l}\text { AI could be a cost- } \\
\text { saving alternative }\end{array}$ & $\begin{array}{l}\text { There were con- } \\
\text { cerns over data } \\
\text { privacy }\end{array}$ & $\begin{array}{l}\text { Users were un- } \\
\text { sure about the } \\
\text { legality of offi- } \\
\text { cial medical } \\
\text { certification and } \\
\text { app trustworthi- } \\
\text { ness }\end{array}$ & NS & $\begin{array}{l}\text { Only a minority } \\
\text { would rely sole- } \\
\text { ly on an AI- } \\
\text { driven app for } \\
\text { assessing health }\end{array}$ \\
\hline $\begin{array}{l}\text { Castagno } \\
\text { and Khalifa } \\
{[43]}\end{array}$ & NS & $\begin{array}{l}\text { In all, } 79 \% \text { of health } \\
\text { care staff believed AI } \\
\text { could be useful or ex- } \\
\text { tremely useful in their } \\
\text { field of work }\end{array}$ & NS & $\begin{array}{l}\text { In all, } 80 \% \text { of } \\
\text { health care staff } \\
\text { believed there } \\
\text { may be serious } \\
\text { privacy issues }\end{array}$ & NS & NS & $\begin{array}{l}\text { Overall, } 10 \% \text { of } \\
\text { health care staff } \\
\text { worried AI will } \\
\text { replace their job }\end{array}$ \\
\hline $\begin{array}{l}\text { Easton et al } \\
\text { [31] }\end{array}$ & NS & NS & NS & $\begin{array}{l}\text { Patients were } \\
\text { not concerned } \\
\text { over data shar- } \\
\text { ing }\end{array}$ & $\begin{array}{l}\text { Patients were } \\
\text { unsure whether } \\
\text { to treat a chat- } \\
\text { bot as a real } \\
\text { physician or an } \\
\text { adviser }\end{array}$ & NS & NS \\
\hline $\begin{array}{l}\text { Gao et al } \\
\text { [22] }\end{array}$ & NS & NS & NS & $\begin{array}{l}\text { Distrust of AI } \\
\text { companies ac- } \\
\text { counted for a } \\
\text { quarter of all } \\
\text { negative opin- } \\
\text { ions among so- } \\
\text { cial media users }\end{array}$ & $\begin{array}{l}\text { Social media } \\
\text { users were pes- } \\
\text { simistic about } \\
\text { the immaturity } \\
\text { of AI technolo- } \\
\text { gy }\end{array}$ & NS & $\begin{array}{l}\text { Less than half } \\
\text { of the social } \\
\text { media posts ex- } \\
\text { pressed that AI } \\
\text { would complete- } \\
\text { ly or partially } \\
\text { replace human } \\
\text { doctors }\end{array}$ \\
\hline $\begin{array}{l}\text { Griffin et al } \\
{[25]}\end{array}$ & NS & $\begin{array}{l}\text { The majority were in- } \\
\text { terested in using a } \\
\text { chatbot to help man- } \\
\text { age medications, re- } \\
\text { fills, communicate } \\
\text { with care teams, and } \\
\text { accountability toward } \\
\text { self-care tasks }\end{array}$ & NS & $\begin{array}{l}\text { There were con- } \\
\text { cerns with chat- } \\
\text { bots providing } \\
\text { too much infor- } \\
\text { mation and in- } \\
\text { vading privacy }\end{array}$ & $\begin{array}{l}\text { There were con- } \\
\text { cerns with chat- } \\
\text { bots making } \\
\text { overwhelming } \\
\text { demands for } \\
\text { lifestyle } \\
\text { changes }\end{array}$ & NS & NS \\
\hline Kim [47] & NS & NS & NS & NS & NS & NS & NS \\
\hline
\end{tabular}




\begin{tabular}{|c|c|c|c|c|c|c|c|}
\hline Study & $\begin{array}{l}\text { Available on } \\
\text { demand and us- } \\
\text { er-friendly }\end{array}$ & Efficiency & Price & $\begin{array}{l}\text { Lack of trust in } \\
\text { data privacy }\end{array}$ & $\begin{array}{l}\text { Lack of trust in } \\
\text { patient safety }\end{array}$ & $\begin{array}{l}\text { Lack of trust in } \\
\text { technology }\end{array}$ & $\begin{array}{l}\text { Concerns over } \\
\text { full automation }\end{array}$ \\
\hline Lai et al [41] & NS & NS & NS & $\begin{array}{l}\text { There were le- } \\
\text { gal difficulties } \\
\text { to access indi- } \\
\text { vidual health } \\
\text { data; regulate } \\
\text { use; strike bal- } \\
\text { ance between } \\
\text { health, social } \\
\text { justice, and } \\
\text { freedom; and } \\
\text { need to achieve } \\
\text { confidentiality } \\
\text { and respect for } \\
\text { privacy }\end{array}$ & NS & NS & NS \\
\hline Li et al [32] & NS & NS & NS & NS & $\begin{array}{l}\text { AI may not un- } \\
\text { derstand com- } \\
\text { plex emotional } \\
\text { problems and } \\
\text { give incurable } \\
\text { diagnoses; and } \\
\text { unsure whether } \\
\text { doctors would } \\
\text { accept the infor- } \\
\text { mation provid- } \\
\text { ed by the AI }\end{array}$ & NS & NS \\
\hline Liu et al [34] & NS & NS & NS & NS & $\begin{array}{l}\text { Majority were } \\
\text { confident that } \\
\text { AI diagnosis } \\
\text { methods would } \\
\text { outperform hu- } \\
\text { man clinician } \\
\text { diagnosis meth- } \\
\text { ods because of } \\
\text { higher accuracy }\end{array}$ & NS & $\begin{array}{l}\text { Majority pre- } \\
\text { ferred to receive } \\
\text { combined diag- } \\
\text { noses from both } \\
\text { AI and human } \\
\text { clinicians }\end{array}$ \\
\hline Liu et al [39] & NS & NS & $\begin{array}{l}\text { Acceptability de- } \\
\text { pends on the ex- } \\
\text { pense of AI diagno- } \\
\text { sis compared with } \\
\text { that of physicians }\end{array}$ & NS & $\begin{array}{l}\text { Accuracy was } \\
\text { deemed the } \\
\text { most important } \\
\text { attribute for AI } \\
\text { uptake }\end{array}$ & NS & NS \\
\hline $\begin{array}{l}\text { Liyanage et } \\
\text { al [44] }\end{array}$ & NS & $\begin{array}{l}\text { Improves efficiency } \\
\text { through decision sup- } \\
\text { port to improve prima- } \\
\text { ry health care process- } \\
\text { es and pattern recogni- } \\
\text { tion in imaging }\end{array}$ & NS & NS & $\begin{array}{l}\text { There were con- } \\
\text { cerns over the } \\
\text { risk of medical } \\
\text { errors, bias, and } \\
\text { secondary ef- } \\
\text { fects of using } \\
\text { AI (eg, insur- } \\
\text { ance) }\end{array}$ & NS & $\begin{array}{l}\text { AI technology } \\
\text { is still not com- } \\
\text { petent to re- } \\
\text { place human } \\
\text { decision-mak- } \\
\text { ing in clinical } \\
\text { scenarios }\end{array}$ \\
\hline $\begin{array}{l}\text { McCradden } \\
\text { et al [36] }\end{array}$ & NS & $\begin{array}{l}\text { Potential for faster } \\
\text { and more accurate } \\
\text { analyses; ability to use } \\
\text { more data }\end{array}$ & NS & $\begin{array}{l}\text { There were con- } \\
\text { cerns about pri- } \\
\text { vacy, commer- } \\
\text { cial motives, } \\
\text { and other risks } \\
\text { and mixed } \\
\text { views about ex- } \\
\text { plicit consent } \\
\text { for research. } \\
\text { Transparency is } \\
\text { needed }\end{array}$ & $\begin{array}{l}\text { It still requires } \\
\text { human verifica- } \\
\text { tion of comput- } \\
\text { er-aided deci- } \\
\text { sions }\end{array}$ & NS & $\begin{array}{l}\text { Fear of losing } \\
\text { human touch } \\
\text { and skills from } \\
\text { overreliance on } \\
\text { machines }\end{array}$ \\
\hline
\end{tabular}




\begin{tabular}{|c|c|c|c|c|c|c|c|}
\hline Study & $\begin{array}{l}\text { Available on } \\
\text { demand and us- } \\
\text { er-friendly }\end{array}$ & Efficiency & Price & $\begin{array}{l}\text { Lack of trust in } \\
\text { data privacy }\end{array}$ & $\begin{array}{l}\text { Lack of trust in } \\
\text { patient safety }\end{array}$ & $\begin{array}{l}\text { Lack of trust in } \\
\text { technology }\end{array}$ & $\begin{array}{l}\text { Concerns over } \\
\text { full automation }\end{array}$ \\
\hline $\begin{array}{l}\text { Milne-Ives } \\
\text { et al [23] }\end{array}$ & $\begin{array}{l}\text { Easy to learn } \\
\text { and use }\end{array}$ & $\begin{array}{l}\text { Speed up the process } \\
\text { of service delivery } \\
\text { and performance. Re- } \\
\text { spondents appreciated } \\
\text { reminders and assis- } \\
\text { tance in forming rou- } \\
\text { tines, chatbot agents } \\
\text { in facilitating learn- } \\
\text { ing, and agents in pro- } \\
\text { viding accountability } \\
\text { (eg, regular check-ins, } \\
\text { follow-ups). Multi- } \\
\text { modal interactions } \\
\text { (eg, voice, touch) } \\
\text { were viewed positive- } \\
\text { ly }\end{array}$ & $\mathrm{NS}$ & $\mathrm{NS}$ & $\begin{array}{l}\text { Unable to suffi- } \\
\text { ciently encom- } \\
\text { pass the real sit- } \\
\text { uational com- } \\
\text { plexity. Elec- } \\
\text { tronic physician } \\
\text { did not have the } \\
\text { ability to go } \\
\text { deep enough, } \\
\text { provide access } \\
\text { to other materi- } \\
\text { als, or provide } \\
\text { enough informa- } \\
\text { tion }\end{array}$ & NS & NS \\
\hline $\begin{array}{l}\text { Nadarzynski } \\
\text { et al [26] }\end{array}$ & $\begin{array}{l}\text { Chatbots were } \\
\text { perceived as a } \\
\text { convenient tool } \\
\text { that could facili- } \\
\text { tate the seeking } \\
\text { of health infor- } \\
\text { mation on the } \\
\text { web }\end{array}$ & $\begin{array}{l}\text { If free at the point of } \\
\text { access, chatbots were } \\
\text { seen as time-saving } \\
\text { and useful platforms } \\
\text { for triaging users to } \\
\text { appropriate health } \\
\text { care services }\end{array}$ & NS & $\begin{array}{l}\text { Some partici- } \\
\text { pants were con- } \\
\text { cerned about } \\
\text { the ability of } \\
\text { the chatbots to } \\
\text { keep sensitive } \\
\text { data secured } \\
\text { and confiden- } \\
\text { tial. The level } \\
\text { of anonymity } \\
\text { offered by chat- } \\
\text { bots was } \\
\text { viewed positive- } \\
\text { ly by several } \\
\text { participants }\end{array}$ & $\begin{array}{l}\text { Risk of harm } \\
\text { from inaccurate } \\
\text { or inadequate } \\
\text { advice. Imma- } \\
\text { ture in perform- } \\
\text { ing a diagnosis } \\
\text { but providing } \\
\text { general health } \\
\text { advice is accept- } \\
\text { able }\end{array}$ & $\begin{array}{l}\text { Uncertain about } \\
\text { the quality, } \\
\text { trustworthiness, } \\
\text { and accuracy of } \\
\text { the health infor- } \\
\text { mation provid- } \\
\text { ed by chatbots }\end{array}$ & NS \\
\hline $\begin{array}{l}\text { Okolo et al } \\
{[42]}\end{array}$ & $\mathrm{NS}$ & $\begin{array}{l}\text { AI app would be able } \\
\text { to perform some of } \\
\text { the manual tasks and } \\
\text { make the work of } \\
\mathrm{CHWs}^{\mathrm{c}} \text { more effi- } \\
\text { cient, and help CHWs } \\
\text { and patients in deci- } \\
\text { sion-making processes }\end{array}$ & NS & NS & $\begin{array}{l}\text { Concerned over } \\
\text { AI failures or } \\
\text { misdiagnoses. } \\
\text { The AI app } \\
\text { might serve to } \\
\text { reinforce the } \\
\text { expertise of } \\
\text { CHWs, improve } \\
\text { patients' under- } \\
\text { standing of the } \\
\text { diagnosis }\end{array}$ & & $\begin{array}{l}\text { AI would never } \\
\text { completely re- } \\
\text { place health } \\
\text { care workers } \\
\text { because of the } \\
\text { need for human } \\
\text { interaction }\end{array}$ \\
\hline
\end{tabular}




\begin{tabular}{|c|c|c|c|c|c|c|c|}
\hline Study & $\begin{array}{l}\text { Available on } \\
\text { demand and us- } \\
\text { er-friendly }\end{array}$ & Efficiency & Price & $\begin{array}{l}\text { Lack of trust in } \\
\text { data privacy }\end{array}$ & $\begin{array}{l}\text { Lack of trust in } \\
\text { patient safety }\end{array}$ & $\begin{array}{l}\text { Lack of trust in } \\
\text { technology }\end{array}$ & $\begin{array}{l}\text { Concerns over } \\
\text { full automation }\end{array}$ \\
\hline $\begin{array}{l}\text { Palanica et } \\
\text { al [27] }\end{array}$ & NS & $\begin{array}{l}\text { Many physicians be- } \\
\text { lieved that chatbots } \\
\text { would be most benefi- } \\
\text { cial for administrative } \\
\text { tasks such as schedul- } \\
\text { ing physician appoint- } \\
\text { ments, locating health } \\
\text { clinics, or providing } \\
\text { medication informa- } \\
\text { tion }\end{array}$ & NS & NS & $\begin{array}{l}\text { Chatbots could } \\
\text { be a risk to pa- } \\
\text { tients if they } \\
\text { self-diagnose } \\
\text { too often and } \\
\text { did not accurate- } \\
\text { ly understand } \\
\text { the diagnoses }\end{array}$ & NS & $\begin{array}{l}\text { Chatbots alone } \\
\text { are not able to } \\
\text { provide effec- } \\
\text { tive care for all } \\
\text { patients because } \\
\text { of limited } \\
\text { knowledge of } \\
\text { personal factors }\end{array}$ \\
\hline $\begin{array}{l}\text { Prakash and } \\
\text { Das [24] }\end{array}$ & $\begin{array}{l}\text { Always avail- } \\
\text { able at the } \\
\text { touch of a but- } \\
\text { ton and user- } \\
\text { friendly }\end{array}$ & NS & $\begin{array}{l}\text { The price of men- } \\
\text { tal health chatbots } \\
\text { could be a decisive } \\
\text { factor in places } \\
\text { with a poor health } \\
\text { insurance system }\end{array}$ & $\begin{array}{l}\text { Data privacy is } \\
\text { a major barrier } \\
\text { that prevents } \\
\text { the adoption of } \\
\text { mental health } \\
\text { chatbots }\end{array}$ & $\begin{array}{l}\text { Chatbots may } \\
\text { be useful in } \\
\text { managing men- } \\
\text { tal health condi- } \\
\text { tions but not } \\
\text { good enough } \\
\text { for complex } \\
\text { problems. May } \\
\text { even be more } \\
\text { harmful to vul- } \\
\text { nerable patients } \\
\text { with poor ad- } \\
\text { vice }\end{array}$ & $\begin{array}{l}\text { Doubtful about } \\
\text { reliability and } \\
\text { functionality }\end{array}$ & $\mathrm{NS}$ \\
\hline $\begin{array}{l}\text { Scheetz et al } \\
{[35]}\end{array}$ & NS & $\begin{array}{l}\text { The top three potential } \\
\text { advantages are im- } \\
\text { proved patient access } \\
\text { to disease screening; } \\
\text { improved diagnostic } \\
\text { confidence; and en- } \\
\text { hanced efficiency, that } \\
\text { is, reduced time spent } \\
\text { by specialists on } \\
\text { monotonous tasks }\end{array}$ & NS & $\begin{array}{l}\text { There were con- } \\
\text { cerns over the } \\
\text { divestment of } \\
\text { health care to } \\
\text { large technolo- } \\
\text { gy and data } \\
\text { companies }\end{array}$ & $\begin{array}{l}\text { There were con- } \\
\text { cerns over medi- } \\
\text { cal liability be- } \\
\text { cause of ma- } \\
\text { chine errors }\end{array}$ & $\begin{array}{l}\text { AI would need } \\
\text { to perform } \\
\text { much more su- } \\
\text { perior to the av- } \\
\text { erage specialist } \\
\text { in screening and } \\
\text { diagnosis }\end{array}$ & $\begin{array}{l}\text { There is decreas- } \\
\text { ing reliance on } \\
\text { medical special- } \\
\text { ists for diagno- } \\
\text { sis and treat- } \\
\text { ment advice }\end{array}$ \\
\hline $\begin{array}{l}\text { Stai et al } \\
{[45]}\end{array}$ & NS & NS & $\begin{array}{l}\text { Almost all }(94 \%) \\
\text { participants were } \\
\text { willing to pay for a } \\
\text { review of medical } \\
\text { imaging by an AI }\end{array}$ & NS & NS & $\begin{array}{l}\text { Nearly equal } \\
\text { trust in AI vs } \\
\text { physician diag- } \\
\text { noses; signifi- } \\
\text { cantly more } \\
\text { likely to trust an } \\
\text { AI diagnosis of } \\
\text { cancer over a } \\
\text { physician's diag- } \\
\text { nosis }\end{array}$ & $\mathrm{NS}$ \\
\hline $\begin{array}{l}\text { Sun and } \\
\text { Medaglia } \\
{[40]}\end{array}$ & NS & NS & $\begin{array}{l}\text { High treatment } \\
\text { costs for patients } \\
\text { but does not make } \\
\text { profits for hospitals }\end{array}$ & $\begin{array}{l}\text { Lack of trust to- } \\
\text { ward AI-based } \\
\text { decisions; uneth- } \\
\text { ical use of } \\
\text { shared data }\end{array}$ & $\begin{array}{l}\text { Doubts in the } \\
\text { ability of AI to } \\
\text { identify coun- } \\
\text { try-specific pa- } \\
\text { tient disease } \\
\text { profiles }\end{array}$ & $\begin{array}{l}\text { There were con- } \\
\text { cerns over the } \\
\text { lack of data inte- } \\
\text { gration; stan- } \\
\text { dards of data } \\
\text { collection, for- } \\
\text { mat, and quali- } \\
\text { ty; algorithm } \\
\text { opacity; and } \\
\text { ability to read } \\
\text { unstructured da- } \\
\text { ta }\end{array}$ & $\mathrm{NS}$ \\
\hline $\begin{array}{l}\text { Tam-Seto et } \\
\text { al [38] }\end{array}$ & $\begin{array}{l}\text { It could support } \\
\text { those not cur- } \\
\text { rently accessing } \\
\text { mental health } \\
\text { services }\end{array}$ & $\begin{array}{l}\text { It would address the } \\
\text { perceived mental } \\
\text { health service gap }\end{array}$ & NS & $\begin{array}{l}\text { No assurance of } \\
\text { users' privacy }\end{array}$ & $\begin{array}{l}\text { Trust in the app, } \\
\text { as it discloses } \\
\text { that the app was } \\
\text { informed by the } \\
\text { Canadian mili- } \\
\text { tary experience } \\
\text { (credibility) }\end{array}$ & $\begin{array}{l}\text { There were } \\
\text { doubts over } \\
\text { overall sustain- } \\
\text { ability }\end{array}$ & NS \\
\hline
\end{tabular}




\begin{tabular}{|c|c|c|c|c|c|c|c|}
\hline Study & $\begin{array}{l}\text { Available on } \\
\text { demand and us- } \\
\text { er-friendly }\end{array}$ & Efficiency & Price & $\begin{array}{l}\text { Lack of trust in } \\
\text { data privacy }\end{array}$ & $\begin{array}{l}\text { Lack of trust in } \\
\text { patient safety }\end{array}$ & $\begin{array}{l}\text { Lack of trust in } \\
\text { technology }\end{array}$ & $\begin{array}{l}\text { Concerns over } \\
\text { full automation }\end{array}$ \\
\hline $\begin{array}{l}\text { Xiang et al } \\
{[33]}\end{array}$ & NS & $\begin{array}{l}\text { Health care workers } \\
\text { prefer AI to alleviate } \\
\text { daily repetitive work } \\
\text { and improve outpa- } \\
\text { tient guidance and } \\
\text { consultation. The cur- } \\
\text { rent auxiliary and par- } \\
\text { tial substitution ef- } \\
\text { fects of AI are recog- } \\
\text { nized by }>90 \% \text { of the } \\
\text { public, and both } \\
\text { groups have positive } \\
\text { attitudes regarding AI } \\
\text { development }\end{array}$ & NS & NS & $\begin{array}{l}\text { Both health care } \\
\text { and non-health } \\
\text { care workers } \\
\text { express more } \\
\text { trust in real doc- } \\
\text { tors than in AI }\end{array}$ & NS & $\begin{array}{l}\text { A very small } \\
\text { minority of } \\
\text { health care and } \\
\text { non-health care } \\
\text { workers expect } \\
\text { that full automa- } \\
\text { tion is likely to } \\
\text { happen }\end{array}$ \\
\hline $\begin{array}{l}\text { Zhang et al } \\
{[46]}\end{array}$ & NS & NS & NS & $\begin{array}{l}\text { There were con- } \\
\text { cerns about cy- } \\
\text { bersecurity }\end{array}$ & NS & $\begin{array}{l}\text { There were con- } \\
\text { cerns about ac- } \\
\text { curacy, reliabili- } \\
\text { ty, quality, and } \\
\text { trustworthiness } \\
\text { of AI outputs, } \\
\text { such as the pre- } \\
\text { dictions and } \\
\text { recommended } \\
\text { medical infor- } \\
\text { mation }\end{array}$ & $\begin{array}{l}\text { Supplementary } \\
\text { service rather } \\
\text { than a replace- } \\
\text { ment of the pro- } \\
\text { fessional health } \\
\text { force is required } \\
\text { for the AI to be } \\
\text { particularly use- } \\
\text { ful in helping } \\
\text { patients to com- } \\
\text { prehend their } \\
\text { physician's diag- } \\
\text { nosis }\end{array}$ \\
\hline
\end{tabular}

${ }^{\mathrm{a} A I}$ : artificial intelligence.

${ }^{b}$ NS: not specified.

${ }^{\mathrm{c}} \mathrm{CHW}$ : community health care worker.

\section{Availability and Ease of Use}

Of the 26 studies, 3 (12\%) studies highlighted the advantage of AI being constantly available without restrictions such as physical location, time, and access to a structured treatment $[24,30,38] ; 3(12 \%)$ other studies also mentioned the appreciation of respondents for how an AI system could collect data remotely in a nonintrusive and user-friendly manner $[23,24,28]$. These studies mostly represented the perceptions of consumers and health care providers [24,30,38] (Multimedia Appendix 3). Only 4\% (1/26) of studies did not mention the population characteristics [24].

\section{Improves Efficiency and Reduces the Cost of Health Care Service Delivery}

In all, 58\% (15/26) of studies highlighted the potential of AI to improve the efficiency of health care service delivery in terms of remote monitoring [28], providing health-related reminders $[23,28]$, increasing the speed and accuracy of health care processes (eg, consultation wait time, triaging, diagnosis, and managing medication refills) [26,29,30,35-37,44], facilitating care team communications, improving care accountability (eg, regular check-ins and follow-ups for information gathering) [23], and taking over repetitive manual tasks (eg, scheduling, patient education, and vital signs monitoring) [27]. Some respondents also appreciated the use of AI to provide a second opinion to physicians' diagnoses or evaluations $[42,46]$. Overall, $12 \%(3 / 26)$ of studies $[24,34,45]$ discussed the potential cost-saving capacity of AI that influences AI acceptability, whereas $4 \%(1 / 26)$ mentioned that the provision of an AI service using IBM Watson caused patients to incur higher treatment costs that did not translate to profits for the hospital after factoring onboarding of the technology [40]. There was a good proportion of representation from the health care and IT staff (53.3\%) [27-29,36,37,40,42,44] and those from the public, including patients (Multimedia Appendix 3). Only 4\% (1/26) of the studies did not mention the population characteristics [24].

\section{Concerns and Mitigation Strategies}

\section{Overview}

Our findings highlight several concerns (Table 2) and mitigation strategies (Table 3). 
Table 3. Needs and mitigation strategies of artificial intelligence (AI) in health care.

\begin{tabular}{|c|c|c|c|c|c|}
\hline Study & $\begin{array}{l}\text { Need for transparen- } \\
\text { cy, credibility, and } \\
\text { regulation }\end{array}$ & $\begin{array}{l}\text { Lack of personalization and } \\
\text { customizability }\end{array}$ & $\begin{array}{l}\text { Perceived empathy and per- } \\
\text { sonification }\end{array}$ & $\begin{array}{l}\text { Design, user experience, and } \\
\text { interconnectedness with } \\
\text { other devices }\end{array}$ & $\begin{array}{l}\text { Educating the public } \\
\text { on AI capabilities }\end{array}$ \\
\hline $\begin{array}{l}\text { Abdi et al } \\
{[28]}\end{array}$ & $N S^{\mathrm{a}}$ & NS & NS & $\begin{array}{l}\text { Implementing user-led de- } \\
\text { sign principles could facili- } \\
\text { tate the acceptability and } \\
\text { uptake of these technologies }\end{array}$ & NS \\
\hline $\begin{array}{l}\text { Abdullah } \\
\text { and Fakieh } \\
\text { [29] }\end{array}$ & NS & NS & NS & NS & $\begin{array}{l}\text { Most respondents } \\
\text { had a general lack of } \\
\text { AI knowledge (mean } \\
\text { score } 2.95 \text { from } 4 \text { ) } \\
\text { and were unaware of } \\
\text { the advantages and } \\
\text { challenges of AI ap- } \\
\text { plications in health } \\
\text { care }\end{array}$ \\
\hline $\begin{array}{l}\text { Baldauf et al } \\
{[30]}\end{array}$ & $\begin{array}{l}\text { Need guarantee of } \\
\text { anonymized trans- } \\
\text { mission and analysis } \\
\text { of personal health } \\
\text { data of users }\end{array}$ & $\begin{array}{ll}\text { - } & \text { Personalized explana- } \\
\text { - } & \text { } \\
\text { - } & \text { Tiseas of analyse information } \\
\text { - } & \text { Recomment cost } \\
& \text { cian's visit } \\
\text { - } & \text { Alternative Therapies } \\
\text { - } & \text { Prevention information } \\
\text { - } & \text { Treatment companion } \\
\text { - } & \text { Mental support } \\
\text { - } & \text { Objectivity and inde- } \\
& \text { pendence }\end{array}$ & $\begin{array}{l}\text { Lack of personal face-to- } \\
\text { face contact with a human } \\
\text { expert }\end{array}$ & NS & NS \\
\hline $\begin{array}{l}\text { Castagno } \\
\text { and Khalifa } \\
{[43]}\end{array}$ & NS & NS & NS & NS & NS \\
\hline $\begin{array}{l}\text { Easton et al } \\
{[31]}\end{array}$ & $\begin{array}{l}\text { Needed clarity on } \\
\text { whether the chatbot } \\
\text { was a physician or } \\
\text { an adviser }\end{array}$ & $\begin{array}{l}\text { The system should allow } \\
\text { personalization }\end{array}$ & $\begin{array}{l}\text { The chatbot should be en- } \\
\text { riched by the ability to de- } \\
\text { tect emotion (distress, fa- } \\
\text { tigue, and irritation) in } \\
\text { speech and nonverbal cues } \\
\text { to build a therapeutic rela- } \\
\text { tionship between the agent } \\
\text { and the patient }\end{array}$ & $\begin{array}{l}\text { Personification of the chat- } \\
\text { bot should be emotionally } \\
\text { expressive. Multi-modal in- } \\
\text { teractions and interconnect- } \\
\text { edness with other consumer } \\
\text { devices were suggested }\end{array}$ & NS \\
\hline $\begin{array}{l}\text { Gao et al } \\
{[22]}\end{array}$ & NS & NS & NS & NS & NS \\
\hline $\begin{array}{l}\text { Griffin et al } \\
{[25]}\end{array}$ & NS & NS & NS & $\begin{array}{l}\text { Some older adults described } \\
\text { limited use of smartphone, } \\
\text { given the small screen or in- } \\
\text { ability to keep track of it }\end{array}$ & NS \\
\hline $\operatorname{Kim}$ [47] & NS & NS & NS & NS & NS \\
\hline Laï et al [41] & $\begin{array}{l}\text { Need for app regula- } \\
\text { tion to create a more } \\
\text { permissive regulato- } \\
\text { ry framework; } \\
\text { achieve confidential- } \\
\text { ity and respect for } \\
\text { privacy }\end{array}$ & NS & NS & NS & NS \\
\hline
\end{tabular}




\begin{tabular}{|c|c|c|c|c|c|}
\hline Study & $\begin{array}{l}\text { Need for transparen- } \\
\text { cy, credibility, and } \\
\text { regulation }\end{array}$ & $\begin{array}{l}\text { Lack of personalization and } \\
\text { customizability }\end{array}$ & $\begin{array}{l}\text { Perceived empathy and per- } \\
\text { sonification }\end{array}$ & $\begin{array}{l}\text { Design, user experience, and } \\
\text { interconnectedness with } \\
\text { other devices }\end{array}$ & $\begin{array}{l}\text { Educating the public } \\
\text { on AI capabilities }\end{array}$ \\
\hline Li et al [32] & $\begin{array}{l}\text { Credibility of the in- } \\
\text { telligent self-diagno- } \\
\text { sis system can be } \\
\text { improved through } \\
\text { transparency (eg, } \\
\text { showing accuracy } \\
\text { scores). State if doc- } \\
\text { tors would accept } \\
\text { information provid- } \\
\text { ed by AI }\end{array}$ & $\begin{array}{l}\text { AI systems may provide } \\
\text { more specific, personalized } \\
\text { information and advice }\end{array}$ & NS & NS & NS \\
\hline Liu et al [34] & NS & NS & NS & NS & NS \\
\hline Liu et al [39] & NS & NS & NS & NS & NS \\
\hline $\begin{array}{l}\text { Liyanage et } \\
\text { al [44] }\end{array}$ & NS & NS & NS & NS & NS \\
\hline $\begin{array}{l}\text { McCradden } \\
\text { et al [36] }\end{array}$ & $\begin{array}{l}\text { Need for transparen- } \\
\text { cy on how and by } \\
\text { whom their data } \\
\text { were used }\end{array}$ & NS & NS & NS & NS \\
\hline $\begin{array}{l}\text { McCradden } \\
\text { et al [37] }\end{array}$ & $\begin{array}{l}\text { Need for transparen- } \\
\text { cy, disclosure, repa- } \\
\text { rations, deidentifica- } \\
\text { tion of data, and use } \\
\text { within trusted institu- } \\
\text { tions }\end{array}$ & NS & NS & NS & NS \\
\hline $\begin{array}{l}\text { Milne-Ives } \\
\text { et al [23] }\end{array}$ & NS & $\begin{array}{l}\text { Need more customization or } \\
\text { availability of feature op- } \\
\text { tions (eg, preformatted or } \\
\text { free-text options) }\end{array}$ & $\begin{array}{l}\text { Need for greater interactivi- } \\
\text { ty or relational skills in con- } \\
\text { versational agents. Respon- } \\
\text { dents liked that the agent } \\
\text { had a personality and } \\
\text { showed empathy, which im- } \\
\text { proves personal connection. } \\
\text { Others had difficulty in em- } \\
\text { pathizing with the agent or } \\
\text { reported disliking its limited } \\
\text { conversation and responses }\end{array}$ & $\begin{array}{l}\text { Interaction was too long, the } \\
\text { use of nonverbal expressions } \\
\text { by the avatar was not appeal- } \\
\text { ing, and there was a lack of } \\
\text { clarity regarding the aim of } \\
\text { the chatbot. Better integra- } \\
\text { tion of the agent with elec- } \\
\text { tronic health record systems } \\
\text { (for a virtual physician) or } \\
\text { health care providers (for an } \\
\text { asthma self-management } \\
\text { chatbot) would be useful }\end{array}$ & NS \\
\hline $\begin{array}{l}\text { Nadarzynski } \\
\text { et al [26] }\end{array}$ & $\begin{array}{l}\text { Need to increase } \\
\text { transparency of infor- } \\
\text { mation source }\end{array}$ & NS & $\begin{array}{l}\text { Lack of empathy and inabil- } \\
\text { ity of chatbots to understand } \\
\text { more emotional issues, espe- } \\
\text { cially in mental health. The } \\
\text { responses given by chatbots } \\
\text { were seen as depersonalized, } \\
\text { cold, and inhuman. They } \\
\text { were perceived as inferior to } \\
\text { physician consultation, al- } \\
\text { though anonymity could fa- } \\
\text { cilitate the disclosure of } \\
\text { more intimate or uncomfort- } \\
\text { able aspects to do with } \\
\text { health }\end{array}$ & NS & $\begin{array}{l}\text { There was a general } \\
\text { lack of familiarity } \\
\text { and understanding of } \\
\text { health chatbots } \\
\text { among participants }\end{array}$ \\
\hline $\begin{array}{l}\text { Okolo et al } \\
\text { [42] }\end{array}$ & NS & NS & NS & NS & NS \\
\hline $\begin{array}{l}\text { Palanica et } \\
\text { al [27] }\end{array}$ & NS & NS & $\begin{array}{l}\text { Many physicians believed } \\
\text { that chatbots cannot display } \\
\text { human emotion }\end{array}$ & NS & NS \\
\hline
\end{tabular}




\begin{tabular}{|c|c|c|c|c|c|}
\hline Study & $\begin{array}{l}\text { Need for transparen- } \\
\text { cy, credibility, and } \\
\text { regulation }\end{array}$ & $\begin{array}{l}\text { Lack of personalization and } \\
\text { customizability }\end{array}$ & $\begin{array}{l}\text { Perceived empathy and per- } \\
\text { sonification }\end{array}$ & $\begin{array}{l}\text { Design, user experience, and } \\
\text { interconnectedness with } \\
\text { other devices }\end{array}$ & $\begin{array}{l}\text { Educating the public } \\
\text { on AI capabilities }\end{array}$ \\
\hline $\begin{array}{l}\text { Prakash and } \\
\text { Das [24] }\end{array}$ & NS & $\begin{array}{l}\text { There were user input restric- } \\
\text { tions during chatbot conver- } \\
\text { sations where the chatbot } \\
\text { forced the users to respond } \\
\text { to a list of choices }\end{array}$ & $\begin{array}{l}\text { Mixed findings on per- } \\
\text { ceived empathy. Some } \\
\text { users perceived the } \\
\text { chatbot to be warm and } \\
\text { friendly, whereas oth- } \\
\text { ers found it to be un- } \\
\text { sympathetic and rude } \\
\text { Mixed findings on } \\
\text { preference for a life- } \\
\text { like chatbot-some felt } \\
\text { it a little creepy and } \\
\text { weird } \\
\text { The nonjudgmental na- } \\
\text { ture of chatbots is a } \\
\text { strong motivator of } \\
\text { adoption. It should re- } \\
\text { spond spontaneously in } \\
\text { a contingent, human- } \\
\text { like manner }\end{array}$ & NS & NS \\
\hline $\begin{array}{l}\text { Scheetz et al } \\
\text { [35] }\end{array}$ & NS & NS & NS & NS & $\begin{array}{l}\text { A minority (13.8\%) } \\
\text { of the participants } \\
\text { felt that the special- } \\
\text { ist training colleges } \\
\text { were adequately pre- } \\
\text { pared for the intro- } \\
\text { duction of AI into } \\
\text { clinical practice. Ed- } \\
\text { ucation was identi- } \\
\text { fied as a priority to } \\
\text { prepare clinicians } \\
\text { for the implementa- } \\
\text { tion of AI in health } \\
\text { care }\end{array}$ \\
\hline $\begin{array}{l}\text { Stai et al } \\
{[45]}\end{array}$ & NS & NS & NS & NS & NS \\
\hline $\begin{array}{l}\text { Sun and } \\
\text { Medaglia } \\
{[40]}\end{array}$ & NS & NS & NS & NS & $\begin{array}{l}\text { Insufficient knowl- } \\
\text { edge on values and } \\
\text { advantages of AI } \\
\text { technology; unrealis- } \\
\text { tic expectations to- } \\
\text { ward AI technology }\end{array}$ \\
\hline $\begin{array}{l}\text { Tam-Seto et } \\
\text { al [38] }\end{array}$ & NS & NS & NS & NS & $\begin{array}{l}\text { Managing the pub- } \\
\text { lic's expectations of } \\
\text { the capabilities of } \\
\text { such an app }\end{array}$ \\
\hline $\begin{array}{l}\text { Xiang et al } \\
{[33]}\end{array}$ & NS & NS & NS & NS & $\begin{array}{l}\text { More than } 90 \% \text { of } \\
\text { health care workers } \\
\text { expressed a willing- } \\
\text { ness to devote time } \\
\text { to learning about AI } \\
\text { and participating in } \\
\text { AI research }\end{array}$ \\
\hline
\end{tabular}




\begin{tabular}{|c|c|c|c|c|c|}
\hline Study & $\begin{array}{l}\text { Need for transparen- } \\
\text { cy, credibility, and } \\
\text { regulation }\end{array}$ & $\begin{array}{l}\text { Lack of personalization and } \\
\text { customizability }\end{array}$ & $\begin{array}{l}\text { Perceived empathy and per- } \\
\text { sonification }\end{array}$ & $\begin{array}{l}\text { Design, user experience, and } \\
\text { interconnectedness with } \\
\text { other devices }\end{array}$ & $\begin{array}{l}\text { Educating the public } \\
\text { on AI capabilities }\end{array}$ \\
\hline $\begin{array}{l}\text { Zhang et al } \\
\text { [46] }\end{array}$ & $\begin{array}{l}\text { Majority of partici- } \\
\text { pants expressed the } \\
\text { need to increase sys- } \\
\text { tem transparency by } \\
\text { explaining how the } \\
\text { AI arrived at its con- } \\
\text { clusion }\end{array}$ & $\begin{array}{l}\text { - Need more personal- } \\
\text { ized and actionable in- } \\
\text { formation } \\
\text { AI should be enhanced } \\
\text { with features that can } \\
\text { help to recommend } \\
\text { personalized questions } \\
\text { to ask physicians }\end{array}$ & $\begin{array}{l}\text { Concerns over lack of empa- } \\
\text { thy }\end{array}$ & NS & NS \\
\hline
\end{tabular}

${ }^{\mathrm{a}} \mathrm{NS}$ : not specified.

\section{Lack of Trust}

\section{Data Privacy}

In all, 58\% (15/26) of studies described the respondents' lack of trust regarding how their personal data will be collected (eg, unknowingly through voice-activated devices) and handled (eg, by whom and how) $[22,24-26,28,30,31,35,36,38,40,41,43,46]$. However, 4\% (1/26) of the studies reported no concerns regarding data sharing. This could be because of the respondents being chronic obstructive pulmonary disease patients who may have been used to their data being shared for clinical decision-making purposes [31]. Potential mitigation strategies suggested were to guarantee anonymity [26] and increase transparency in how the collected data will be used (eg, by which third party and how) [24,37]. There was a good proportion of representation from the general public, including patients $(53.3 \%)$ [22,24-26,30,31,37,38,46] and health care providers and IT staff (Multimedia Appendix 3).

\section{Patient Safety}

Of the 26 studies, 21 (81\%) discussed the respondents' lack of trust in an AI to ensure patient safety while performing its tasks, especially regarding providing accurate information on rare conditions or unexpected situations [22-27,29-42,44]. Other concerns were regarding the credibility of AI-based recommendations (eg, whether it was validated by medical professionals) $[30,32]$, maturity in the technology to provide safe and realistic recommendations [22,25], medical liability from the risk of medical errors and bias [26,35,36,44], secondary effects of AI-based diagnoses such as insurance claims [44], and miscommunications [26]. The potential mitigation strategies suggested were the provision of AI-specific regulations $[30,31,41]$, transparency in its credibility, how a recommendation is derived (eg, showing who developed the system and the system reasoning and reliability based on information source and personal information), and its accuracy [32,38]. In contrast, $4 \%(1 / 26)$ of studies reported that the respondents were confident that the AI would outperform human clinical diagnoses because of higher accuracy and lower human errors [39]. Most respondents accepted AI in providing general health advice to minor ailments. Most of the responses represented the voices of the public, including patients (66.6\%) [22-26,30-32,34,35,37-40] (Multimedia Appendix 3).

\section{Technology}

Of the 26 studies, 6 (23\%) studies discussed the participants' lack of trust in the maturity of AI technology in providing reliable and accurate information to support health-related predictions and recommendations $[24,26,35,38,40,46]$. This could be related to concerns over the lack of integration and synthesis of information from various sources, standardization of data collection, and the overall sustainability of AI-assisted health care service delivery $[40,45]$. However, $8 \%(2 / 26)$ of studies reported that respondents had similar trust in $\mathrm{AI}$ as compared with a human physician's diagnoses $[28,45]$. Possible mitigation strategies include increasing system transparency and reporting system accuracies [26,46]. Only 8\% (2/26) of studies represented the voices of health care and IT staff [35,40,49] (Multimedia Appendix 3).

\section{Potential Impacts of Full Automation}

In all, 46\% (12/26) of studies discussed the perceptions of respondents on the possibility and impacts of full automation on the health care industry, especially in terms of diagnoses, all of which reported that it is unlikely that AI will completely replace health care professionals $[22,27,29,30,33,35,36,39$, $42-44,46]$. This could largely be because of the immaturity of AI technology and its limitations in providing human-like interactions (which build trust) [27]. Instead, many patients preferred a combination of both $\mathrm{AI}$ and human physicians in diagnoses to achieve a more accurate and comprehensive evaluation $[30,39]$. Most of the responses represented the voices of health care and IT staff (58.3\%) [27,29,35,36,42-44] (Multimedia Appendix 3).

\section{Needs to Improve Adoption of AI in Health Care}

Besides the needs highlighted to mitigate the concerns, several additional features were found to potentially improve the adoption of AI in health care (Table 3).

\section{Enhance Personalization and Customizability}

Of the 26 studies, 6 (23\%) studies discussed the need for AI to personalize information such as the explanation of diagnoses, recommendations, patient education, and even pertinent questions or issues to raise to their physicians $[23,24,30-32,46]$. Some studies also mentioned the need to customize chatbot features according to user preferences (for fixed options or free-texts) [23,24]. 


\section{Enhance Empathy and Personification of AI-Enabled Chatbots and Avatars}

In all, 27\% (7/26) of studies highlighted the respondents' concern over the lack of empathy, which is a crucial element of human interaction to build trust between service providers and consumers. However, empathy must be displayed tactfully in verbal and nonverbal expressions such that it does not appear to be "creepy and weird," especially in populations with mental health issues [24]. Personification was also emphasized to increase the relatability, connection, and appeal to interact with the chatbot or avatar [23]. Perceived anonymity in interacting with the chatbot was also highlighted to assist in communication regarding sensitive topics [26].

\section{Enhance User Experience, Design, and Interconnectedness With Other Devices}

Overall, $15 \%(4 / 26)$ of studies described the need to improve user experience to increase user engagement with AI [23,25,28,31]. Strategies include needs-based interaction timing, the use of suitable verbal and nonverbal expressions, interconnectedness with other information sources (eg, electronic health record), apps (eg, calendar), and devices (eg, smart home technology-enabled devices).

\section{Educate the Public on AI Capabilities}

Of the 26 studies, 6 (23\%) studies highlighted the lack of public and clinical awareness on the capabilities of AI in health care, of which the majority of the respondents expressed their willingness to learn $[26,29,33,35,38,40]$. A better understanding of the advantages and disadvantages of $\mathrm{AI}$ in health care could enhance the health care service delivery efficiency while balancing the expectations from it.

\section{Discussion}

\section{Principal Findings}

On the basis of the 26 articles included in this scoping review, we identified the perceptions and needs of various populations in the use of AI for general, primary, and community health care; chronic diseases self-management; self-diagnosis; mental health; and diagnostic procedures. However, the use of AI in health care remains challenged by the common perceptions, concerns, and unmet needs of various stakeholders such as patients, health care professionals, governmental or legal regulatory bodies, software developers, and industrial providers. Simply introducing AI into health care systems without understanding the needs of stakeholders will not lead to a sustainable change [50].

Our results showed that, similar to most ITs, AI was generally favored for its on-demand availability, ease of use, potential to improve efficiency, and reduce the cost of health care service delivery. These features could enhance patients' compliance to health care treatments and recommendations that may be inaccessible or inconvenient. For example, patients are traditionally required to commit to a physician's consultative appointment that could be relatively inflexible because of a long list of patients, and one could be forced to skip the consultation because of a conflict in their schedule. AI confers the benefit of information collection and dissemination beyond the constraints of time and place, which have been shown to improve medication adherence through an AI-based smartphone app [51] and diet and exercise adherence through an AI-based virtual health assistant [52]. Our findings also demonstrated that AI is valued for its potential to speed up health care processes such as diagnosis, waiting time, communication with care teams, decisional support, and other routine tasks (eg, progress monitoring) that can be automated. This increase in service delivery efficiency frees up time and resources for clinicians to focus on tasks that involve more unexpected variabilities such as dealing with rare disease management and interacting with patients, thereby reducing the risk of burnout, job dissatisfaction, and manpower shortage [53].

Although our findings showed high rates of acceptability, concerns were raised about the lack of trust (in data privacy, patient safety, and technology maturity) and the impacts of AI-driven automation on health care job security and health care services. Ethical controversies surrounding the use of AI in health care have been long-standing. Although there are increasingly more regulatory guidelines available, such as those developed by the World Health Organization [54] and the European Union [55], the use of AI in health care remains debatable because of the challenges in ensuring data privacy and proper data use [56]. This is especially true when data collection modes are conducted through third-party apps, such as Facebook Messenger (Meta Platforms), of which privacy policies are governed by technology companies and not health care institutions [24]. Moreover, although there are privacy and security precautionary measures, the increasing reports of data leaks and vulnerabilities in electronic medical record databases erode population trust. Future security and transparency measures could consider the use of blockchain technology, and privacy laws should be properly delineated and transparent [57].

This review also found the need to enhance the personalization and customizability of information provided by AI, the incorporation of empathy and personification in AI-based conversational agents, the user experience through better design and interconnectedness with other devices and systems, and the need to educate the public on AI capabilities. Concerning personalized health care, reports generated by AI should be integrated and explained in accordance with each individual's demographic and clinical profile to facilitate self-management [46]. We also identified the need for AI to not only assist in the understanding of patients' medical condition but also the provision of relevant treatment options and personalized recommendations with intuitive actions provided (eg, a button to call an ambulance when deemed necessary by the AI) [31]. This coincides with existing studies that highlight the predictive power of AI in providing support to preventive disease onset or deterioration through interventions tailored according to user preferences [58]. For example, AI has been used to provide just-in-time adaptive interventions that prompt users to perform healthy behavior changes (eg, healthy diet and exercise and smoking cessation) based on constant data collection of their behaviors and preferences [49]. However, the data collection of users' behavioral or clinical information should also consider the customizability of input options (eg, providing predefined 
options or allowing for free-text input) to enhance the usability and adoption of such systems, depending on user preferences [24]. Personification of AI-based conversational agents to express human-like identity, personality, empathy, and emotions was also highlighted as an area of improvement to enhance human-chatbot interactions and eventually user adoption [59]. It was also important for the AI systems to be accessible through various devices (eg, tablets, televisions, laptops, and smart home appliances) and modes (eg, text and speech) for the convenience of information consumption and data collection. Finally, our findings suggest a need to address the knowledge deficit in the definition, capacity, and functions of AI. This could be done by cultivating AI literacy and exposure from childhood [60] and incorporating the AI curriculum in health care training and upgrading courses [61].

Overall, our study findings are consistent with well-established theories such as the Technology Acceptance Model, of which the second version proposed by Venkatesh and Davis [62] posits that technology acceptance is strongly associated with the perceived usefulness and perceived ease of use, which are influenced by subjective norms, images, job relevance, output quality, result demonstrability, experience, and voluntariness [63]. Therefore, to enhance the acceptability of AI in health care applications, its perceived usefulness over and above the current standard practices such as capacity to increase service delivery efficiency and community-based self-diagnostic accuracy should be emphasized. Such messages should be designed to be relevant to the individual and organizational adopters of a social system through various communication channels and change agents (ie, gatekeepers and opinion leaders). Such messages should be persuasive to spark five stages of adoption, namely, knowledge, persuasion, decision, implementation, and confirmation, known as the diffusion of innovation theory by Rogers [64]. Different strategies are also needed to correspond with the different categories of adopters, namely, the innovators, early adopters, early majority, late majority, and laggards. Different rates of technology adoption are associated with one's risk tolerance related to higher social economic status, education level, and financial stability [65]. An example is the case of AI adoption in chronic disease early detection and management in the United Arab Emirates. Success was attributed to the managerial, organizational, operational, and IT infrastructure factors that contribute to the factors of the Technology Acceptance Model [66]. However, advanced technologies such as AI continue to be relatively expensive and require eHealth literacy, which may widen the digital divide, and therefore the data divide and health disparity among societies. According to a report published in The Lancet, the internet remains inaccessible to approximately $50 \%$ of the global population because of a digital divide [67]. In addition, there are specific guidelines on the implementation of AI in health care service delivery, such as the quality of data and certification of AI systems, which may deter adoption [68].

\section{Limitations}

This study had several limitations. First, only articles written in English were retrieved, possibly limiting the comprehensiveness of our findings. However, we conducted a search on Google Scholar to supplement the electronic database search for more relevant papers. Second, the studies were largely heterogeneous in their study designs, research aims, and data collection methods. Third, there were limited studies on the perceptions of AI and clinical researchers who could provide outlooks on the perceptions of the general public. Finally, the public's perceptions of AI in health care may be limited by their knowledge of the definitions and capabilities of AI, as highlighted in our findings that there is a need to enhance the public's knowledge on AI. Therefore, the priority or importance of each perception and need could not be evaluated. The inclusion of articles based on our definition of AI could also have limited the scope of this study. Studies that considered different definitions of AI may have been excluded.

\section{Recommendations for Future Design and Research}

This study highlighted the perceptions and needs of AI to enhance its adoption in health care. However, one major challenge lies in the extent to which $\mathrm{AI}$ is tailored according to each individual's unique preference, and if such preferences are largely varied, how data can be aggregated for analyses and applicability in specific health care applications. Therefore, future studies that use AI should not only consider the issues raised in this study but also clarify the applicability in their applications and target population. A prior needs-based analysis is recommended before the development of AI systems.

\section{Conclusions}

Although AI is valued for its $24 / 7$ availability in health care service delivery, ease of use, and capacity to improve health care service provision efficiency, concerns over trust in data privacy, information credibility, and technological maturity remain. Although several mitigation strategies such as enhancing transparency over predictive accuracy and information sources were identified, other areas of improvement were also highlighted. Future studies and AI development should consider the points raised in this study to enhance the adoption and enhancement of AI to improve health care service delivery.

\section{Acknowledgments}

This research was supported by the National University Health System Internal Grant Funding under grant NUHSRO/2021/063/RO5+6/FMPCHSRG-Mar21/01 and the National Research Foundation, Singapore, under its Strategic Capabilities Research Centres Funding Initiative. Any opinions, findings, conclusions, or recommendations expressed in this material are those of the author or authors and do not reflect the views of the National University Health System or the National Research Foundation, Singapore. 


\section{Conflicts of Interest}

None declared.

\section{Multimedia Appendix 1}

PRISMA (Preferred Reporting Items for Systematic Reviews and Meta-Analyses) checklist.

[DOCX File, 16 KB-Multimedia Appendix 1]

\section{Multimedia Appendix 2}

Database search details.

[DOCX File, 14 KB-Multimedia Appendix 2]

\section{Multimedia Appendix 3}

Study characteristics.

[DOCX File, 21 KB-Multimedia Appendix 3]

\section{Multimedia Appendix 4}

Acceptability of artificial intelligence use in health care.

[DOCX File, 16 KB-Multimedia Appendix 4]

\section{References}

1. Panch T, Szolovits P, Atun R. Artificial intelligence, machine learning and health systems. J Glob Health 2018

Dec;8(2):020303 [FREE Full text] [doi: 10.7189/jogh.08.020303] [Medline: 30405904]

2. Chew HS, Ang WH, Lau Y. The potential of artificial intelligence in enhancing adult weight loss: a scoping review. Public Health Nutr 2021 Jun;24(8):1993-2020 [FREE Full text] [doi: 10.1017/S1368980021000598] [Medline: 33592164]

3. Panch T, Pearson-Stuttard J, Greaves F, Atun R. Artificial intelligence: opportunities and risks for public health. Lancet Digit Health 2019 May;1(1):13-14. [doi: 10.1016/s2589-7500(19)30002-0]

4. Arora A. Conceptualising artificial intelligence as a digital healthcare innovation: an introductory review. Med Devices (Auckl) 2020 Aug 20;13:223-230 [FREE Full text] [doi: 10.2147/MDER.S262590] [Medline: 32904333]

5. Dilsizian SE, Siegel EL. Artificial intelligence in medicine and cardiac imaging: harnessing big data and advanced computing to provide personalized medical diagnosis and treatment. Curr Cardiol Rep 2014 Jan;16(1):441. [doi: 10.1007/s11886-013-0441-8] [Medline: 24338557]

6. Hashimoto D, Rosman G, Rus D, Meireles O. Artificial intelligence in surgery: promises and perils. Ann Surg 2018 Jul;268(1):70-76 [FREE Full text] [doi: 10.1097/SLA.0000000000002693] [Medline: 29389679]

7. Stein N, Brooks K. A fully automated conversational artificial intelligence for weight loss: longitudinal observational study among overweight and obese adults. JMIR Diabetes 2017 Nov 01;2(2):e28 [FREE Full text] [doi: 10.2196/diabetes.8590] [Medline: 30291087$]$

8. Sahoo D, Hao W, Ke S, Xiongwei W, Le H, Achananuparp P, et al. FoodAI: food image recognition via deep learning for smart food logging. In: Proceedings of the 25th ACM SIGKDD International Conference on Knowledge Discovery \& Data Mining. 2019 Presented at: 25th ACM SIGKDD International Conference on Knowledge Discovery \& Data Mining; Aug 4 - 8, 2019; Anchorage AK USA. [doi: 10.1145/3292500.3330734]

9. Topol EJ. High-performance medicine: the convergence of human and artificial intelligence. Nat Med 2019 Jan;25(1):44-56. [doi: 10.1038/s41591-018-0300-7] [Medline: $\underline{\text { 30617339] }}$

10. Yu K, Beam AL, Kohane IS. Artificial intelligence in healthcare. Nat Biomed Eng 2018 Oct;2(10):719-731. [doi: 10.1038/s41551-018-0305-z] [Medline: 31015651]

11. Beam AL, Kohane IS. Translating artificial intelligence into clinical care. J Am Med Assoc 2016 Dec 13;316(22):2368-2369. [doi: 10.1001/jama.2016.17217] [Medline: 27898974]

12. Lu Y, Xiao Y, Sears A, Jacko JA. A review and a framework of handheld computer adoption in healthcare. Int J Med Inform 2005 Jun;74(5):409-422. [doi: 10.1016/j.ijmedinf.2005.03.001] [Medline: 15893264]

13. Or CK, Karsh B. A systematic review of patient acceptance of consumer health information technology. $\mathrm{J}$ Am Med Informatics Assoc 2009 Jul 01;16(4):550-560. [doi: 10.1197/jamia.m2888]

14. Yusif S, Soar J, Hafeez-Baig A. Older people, assistive technologies, and the barriers to adoption: a systematic review. Int J Med Inform 2016 Oct;94:112-116. [doi: 10.1016/j.ijmedinf.2016.07.004] [Medline: 27573318]

15. Ethics guidelines for trustworthy AI. European Commission. URL: https://ec.europa.eu/futurium/en/ai-alliance-consultation. 1.html [accessed 2021-12-28]

16. Ting DS, Liu Y, Burlina P, Xu X, Bressler NM, Wong TY. AI for medical imaging goes deep. Nat Med 2018 May;24(5):539-540. [doi: 10.1038/s41591-018-0029-3] [Medline: 29736024] 
17. Quiroz JC, Laranjo L, Kocaballi AB, Berkovsky S, Rezazadegan D, Coiera E. Challenges of developing a digital scribe to reduce clinical documentation burden. NPJ Digit Med 2019;2:114 [FREE Full text] [doi: 10.1038/s41746-019-0190-1] [Medline: 31799422$]$

18. Lysaght T, Lim HY, Xafis V, Ngiam KY. Ai-assisted decision-making in healthcare: the application of an ethics framework for big data in health and research. Asian Bioeth Rev 2019 Sep;11(3):299-314 [FREE Full text] [doi:

10.1007/s41649-019-00096-0] [Medline: 33717318]

19. Delipetrev B, Tsinaraki C, Kostic U. Historical Evolution of Artificial Intelligence. Luxembourg: Publications Office of the European Union; 2020.

20. Arksey H, O'Malley L. Scoping studies: towards a methodological framework. Int J Soc Res Methodol 2005 Feb;8(1):19-32. [doi: 10.1080/1364557032000119616]

21. Tricco AC, Lillie E, Zarin W, O'Brien KK, Colquhoun H, Levac D, et al. PRISMA Extension for Scoping Reviews (PRISMA-ScR): checklist and explanation. Ann Intern Med 2018 Oct 02;169(7):467-473 [FREE Full text] [doi: 10.7326/M18-0850] [Medline: 30178033]

22. Gao S, He L, Chen Y, Li D, Lai K. Public perception of artificial intelligence in medical care: content analysis of social media. J Med Internet Res 2020 Jul 13;22(7):e16649 [FREE Full text] [doi: 10.2196/16649] [Medline: 32673231]

23. Milne-Ives M, de Cock C, Lim E, Shehadeh MH, de Pennington N, Mole G, et al. The effectiveness of artificial intelligence conversational agents in health care: systematic review. J Med Internet Res 2020 Oct 22;22(10):e20346 [FREE Full text] [doi: 10.2196/20346] [Medline: 33090118]

24. Prakash A, Das S. Intelligent conversational agents in mental healthcare services: a thematic analysis of user perceptions. Pacific Asia J Assoc Inf Syst 2020:1-34 [FREE Full text]

25. Griffin A, Xing Z, Mikles S, Bailey S, Khairat S, Arguello J, et al. Information needs and perceptions of chatbots for hypertension medication self-management: a mixed methods study. JAMIA Open 2021 Apr;4(2):ooab021 [FREE Full text] [doi: 10.1093/jamiaopen/ooab021] [Medline: 33898936]

26. Nadarzynski T, Miles O, Cowie A, Ridge D. Acceptability of artificial intelligence (AI)-led chatbot services in healthcare: a mixed-methods study. Digit Health 2019;5:2055207619871808 [FREE Full text] [doi: 10.1177/2055207619871808] [Medline: 31467682]

27. Palanica A, Flaschner P, Thommandram A, Li M, Fossat Y. Physicians' perceptions of chatbots in health care: cross-sectional web-based survey. J Med Internet Res 2019 Apr 05;21(4):e12887 [FREE Full text] [doi: 10.2196/12887] [Medline: 30950796]

28. Abdi S, Witte LD, Hawley M. Exploring the potential of emerging technologies to meet the care and support needs of older people: a delphi survey. Geriatrics (Basel) 2021 Feb 13;6(1):19 [FREE Full text] [doi: 10.3390/geriatrics6010019] [Medline: 33668557]

29. Abdullah R, Fakieh B. Health care employees' perceptions of the use of artificial intelligence applications: survey study. $\mathbf{J}$ Med Internet Res 2020 May 14;22(5):e17620 [FREE Full text] [doi: 10.2196/17620] [Medline: 32406857]

30. Baldauf M, Fröehlich P, Endl R. Trust me, I'm a doctor - user perceptions of AI-driven apps for mobile health diagnosis. In: Proceedings of the 19th International Conference on Mobile and Ubiquitous Multimedia. 2020 Presented at: MUM 2020: 19th International Conference on Mobile and Ubiquitous Multimedia; Nov 22 - 25, 2020; Essen Germany. [doi: $10.1145 / 3428361.3428362]$

31. Easton K, Potter S, Bec R, Bennion M, Christensen H, Grindell C, et al. A virtual agent to support individuals living with physical and mental comorbidities: co-design and acceptability testing. J Med Internet Res 2019 May 30;21(5):e12996 [FREE Full text] [doi: 10.2196/12996] [Medline: 31148545]

32. Li W, Fan X, Zhu H, Wu J, Teng D. Research on the influencing factors of user trust based on artificial intelligence self diagnosis system. In: Proceedings of the ACM Turing Celebration Conference. 2020 Presented at: ACM Turing Celebration Conference; May 22 - 24, 2020; Hefei China. [doi: 10.1145/3393527.3393561]

33. Xiang Y, Zhao L, Liu Z, Wu X, Chen J, Long E, et al. Implementation of artificial intelligence in medicine: status analysis and development suggestions. Artif Intell Med 2020 Jan;102:101780. [doi: 10.1016/j.artmed.2019.101780] [Medline: 31980086]

34. Liu T, Tsang W, Xie Y, Tian K, Huang F, Chen Y, et al. Preferences for artificial intelligence clinicians before and during the COVID-19 pandemic: discrete choice experiment and propensity score matching study. J Med Internet Res 2021 Mar 02;23(3):e26997 [FREE Full text] [doi: 10.2196/26997] [Medline: 33556034]

35. Scheetz J, Rothschild P, McGuinness M, Hadoux X, Soyer HP, Janda M, et al. A survey of clinicians on the use of artificial intelligence in ophthalmology, dermatology, radiology and radiation oncology. Sci Rep 2021 Mar 04;11(1):5193 [FREE Full text] [doi: 10.1038/s41598-021-84698-5] [Medline: 33664367]

36. McCradden MD, Baba A, Saha A, Ahmad S, Boparai K, Fadaiefard P, et al. Ethical concerns around use of artificial intelligence in health care research from the perspective of patients with meningioma, caregivers and health care providers: a qualitative study. CMAJ Open 2020;8(1):90-95 [FREE Full text] [doi: 10.9778/cmajo.20190151] [Medline: 32071143]

37. McCradden MD, Sarker T, Paprica PA. Conditionally positive: a qualitative study of public perceptions about using health data for artificial intelligence research. BMJ Open 2020 Oct 28;10(10):e039798 [FREE Full text] [doi:

10.1136/bmjopen-2020-039798] [Medline: 33115901] 
38. Tam-Seto L, Wood VM, Linden B, Stuart H. Perceptions of an AI-supported mobile app for military health in the Canadian armed forces. Milit Behav Health 2020 Nov 13;9(3):247-254. [doi: 10.1080/21635781.2020.1838364]

39. Liu T, Tsang W, Huang F, Lau OY, Chen Y, Sheng J, et al. Patients' preferences for artificial intelligence applications versus clinicians in disease diagnosis during the SARS-CoV-2 pandemic in China: discrete choice experiment. J Med Internet Res 2021 Feb 23;23(2):e22841 [FREE Full text] [doi: 10.2196/22841] [Medline: 33493130]

40. Sun TQ, Medaglia R. Mapping the challenges of Artificial Intelligence in the public sector: evidence from public healthcare. Govern Inform Q 2019 Apr;36(2):368-383. [doi: 10.1016/j.giq.2018.09.008]

41. Laï M, Brian M, Mamzer M. Perceptions of artificial intelligence in healthcare: findings from a qualitative survey study among actors in France. J Transl Med 2020 Jan 09;18(1):14 [FREE Full text] [doi: 10.1186/s12967-019-02204-y] [Medline: 31918710]

42. Okolo C, Kamath S, Dell N, Vashistha A. "It cannot do all of my work": community health worker perceptions of AI-enabled mobile health applications in rural India. In: Proceedings of the $2021 \mathrm{CHI}$ Conference on Human Factors in Computing Systems. 2021 Presented at: CHI Conference on Human Factors in Computing Systems; May 8 - 13, 2021; Yokohama Japan. [doi: 10.1145/3411764.3445420]

43. Castagno S, Khalifa M. Perceptions of artificial intelligence among healthcare staff: a qualitative survey study. Front Artif Intell 2020 Oct 21;3:578983 [FREE Full text] [doi: 10.3389/frai.2020.578983] [Medline: 33733219]

44. Liyanage H, Liaw S, Jonnagaddala J, Schreiber R, Kuziemsky C, Terry AL, et al. Artificial intelligence in primary health care: perceptions, issues, and challenges. Yearb Med Inform 2019 Aug;28(1):41-46 [FREE Full text] [doi: 10.1055/s-0039-1677901] [Medline: 31022751]

45. Stai B, Heller N, McSweeney S, Rickman J, Blake P, Vasdev R, et al. Public perceptions of artificial intelligence and robotics in medicine. J Endourol 2020 Oct;34(10):1041-1048 [FREE Full text] [doi: 10.1089/end.2020.0137] [Medline: 32611217]

46. Zhang Z, Citardi D, Wang D, Genc Y, Shan J, Fan X. Patients' perceptions of using artificial intelligence (AI)-based technology to comprehend radiology imaging data. Health Informatics J 2021;27(2):14604582211011215 [FREE Full text] [doi: 10.1177/14604582211011215] [Medline: 33913359]

47. Kim H. An analysis of the need for aid tools in dementia patients: focusing on the normal elderly, dementia patients, and caregivers of dementia patients. Ind J Public Health Res Develop 2019;10(11):4399. [doi: 10.5958/0976-5506.2019.04300.6]

48. Kim S, Kim J, Badu-Baiden F, Giroux M, Choi Y. Preference for robot service or human service in hotels? Impacts of the COVID-19 pandemic. Int J Hospitality Manag 2021 Feb;93:102795. [doi: 10.1016/j.ijhm.2020.102795]

49. Nahum-Shani I, Smith S, Spring B, Collins L, Witkiewitz K, Tewari A, et al. Just-in-Time Adaptive Interventions (JITAIs) in mobile health: key components and design principles for ongoing health behavior support. Ann Behav Med 2018 May 18;52(6):446-462 [FREE Full text] [doi: 10.1007/s12160-016-9830-8] [Medline: 27663578]

50. Panch T, Mattie H, Celi LA. The "inconvenient truth" about AI in healthcare. NPJ Digit Med 2019;2:77 [FREE Full text] [doi: 10.1038/s41746-019-0155-4] [Medline: 31453372]

51. Roosan D, Chok J, Karim M, Law AV, Baskys A, Hwang A, et al. Artificial intelligence-powered smartphone app to facilitate medication adherence: protocol for a human factors design study. JMIR Res Protoc 2020 Nov 09;9(11):e21659 [FREE Full text] [doi: 10.2196/21659] [Medline: 33164898]

52. Davis CR, Murphy KJ, Curtis RG, Maher CA. A process evaluation examining the performance, adherence, and acceptability of a physical activity and diet artificial intelligence virtual health assistant. Int J Environ Res Public Health 2020 Dec 07;17(23):9137 [FREE Full text] [doi: 10.3390/ijerph17239137] [Medline: 33297456]

53. Meskó B, Hetényi G, Győrffy Z. Will artificial intelligence solve the human resource crisis in healthcare? BMC Health Serv Res 2018 Jul 13;18(1):545 [FREE Full text] [doi: 10.1186/s12913-018-3359-4] [Medline: $\underline{30001717]}$

54. Ethics and Governance of Artificial Intelligence for Health: WHO Guidance. Geneva: World Health Organization; 2021.

55. White paper on Artificial Intelligence: a European approach to excellence and trust. European Commission. 2020. URL: https://ec.europa.eu/info/publications/white-paper-artificial-intelligence-european-approach-excellence-and-trust en [accessed 2021-12-28]

56. Lee D, Yoon SN. Application of artificial intelligence-based technologies in the healthcare industry: opportunities and challenges. Int J Environ Res Public Health 2021 Jan 01;18(1):271 [FREE Full text] [doi: 10.3390/ijerph18010271] [Medline: $\underline{33401373]}$

57. Wahl B, Cossy-Gantner A, Germann S, Schwalbe NR. Artificial intelligence (AI) and global health: how can AI contribute to health in resource-poor settings? BMJ Glob Health 2018;3(4):e000798 [FREE Full text] [doi: 10.1136/bmjgh-2018-000798] [Medline: 30233828$]$

58. Shaban-Nejad A, Michalowski M, Buckeridge D. Health intelligence: how artificial intelligence transforms population and personalized health. NPJ Digit Med 2018 Oct 2;1:53 [FREE Full text] [doi: 10.1038/s41746-018-0058-9] [Medline: 31304332]

59. Chaves AP, Gerosa MA. How should my chatbot interact? A survey on social characteristics in human-chatbot interaction design. Int J Hum Comput Interact 2020 Nov 08;37(8):729-758. [doi: 10.1080/10447318.2020.1841438]

60. Teaching tech to talk: K-12 conversational artificial intelligence literacy curriculum and development tools. arXiv. 2020. URL: https://arxiv.org/abs/2009.05653 [accessed 2021-12-28] 
61. Wood EA, Ange BL, Miller DD. Are we ready to integrate artificial intelligence literacy into medical school curriculum: students and faculty survey. J Med Educ Curric Dev 2021 Jun 23;8:23821205211024078 [FREE Full text] [doi: 10.1177/23821205211024078] [Medline: $\underline{34250242]}$

62. Venkatesh V, Davis FD. A theoretical extension of the technology acceptance model: four longitudinal field studies. Manag Sci 2000 Feb;46(2):186-204. [doi: 10.1287/mnsc.46.2.186.11926]

63. Marangunić N, Granić A. Technology acceptance model: a literature review from 1986 to 2013. Univ Access Inf Soc 2014 Feb 16;14(1):81-95. [doi: 10.1007/s10209-014-0348-1]

64. Kaminski J. Diffusion of innovation theory. Can J Nursing Inf 2011;6(2):1-6. [doi: 10.1097/cin.0000000000000072]

65. Kwon H, Chidambaram L. A test of the technology acceptance model: the case of cellular telephone adoption. In: Proceedings of the 33rd Annual Hawaii International Conference on System Sciences. 2000 Presented at: 33rd Annual Hawaii International Conference on System Sciences; Jan 7, 2000; Maui, HI, USA. [doi: 10.1109/hicss.2000.926607]

66. Alhashmi S, Salloum S, Mhamdi C. Implementing artificial intelligence in the United Arab Emirates healthcare sector: an extended technology acceptance model. Int J Inf Technol Lang Stud 2019:27-42 [FREE Full text]

67. Makri A. Bridging the digital divide in health care. Lancet Digit Health 2019 Sep;1(5):204-205. [doi: 10.1016/s2589-7500(19)30111-6]

68. Thinking on its own: AI in the NHS. Reform Research Trust. URL: https://reform.uk/research/thinking-its-own-ai-nhs [accessed 2021-12-28]

\section{Abbreviations}

AGI: artificial general intelligence

AI: artificial intelligence

ANI: artificial narrow intelligence

IT: information technology

PRISMA: Preferred Reporting Items for Systematic Reviews and Meta-Analyses

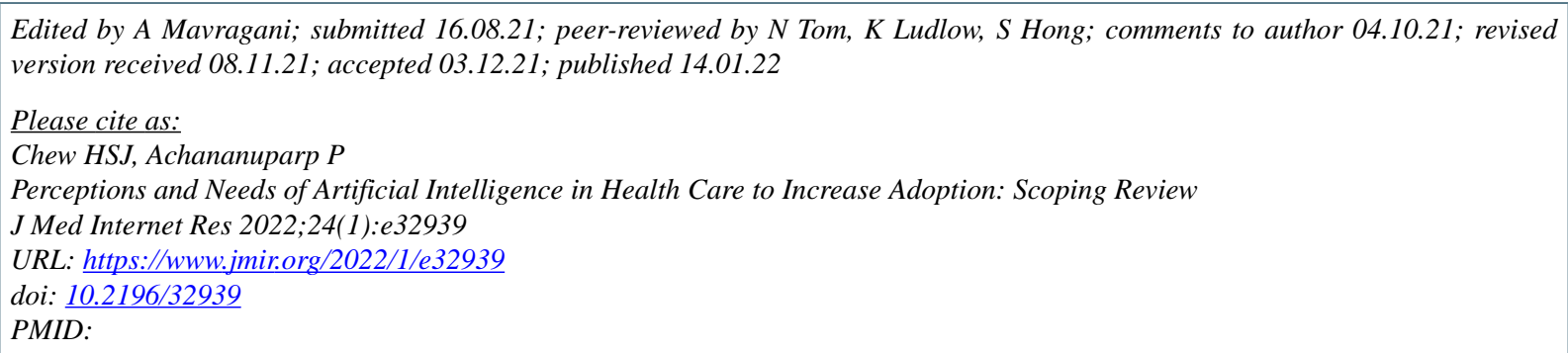

(CHan Shi Jocelyn Chew, Palakorn Achananuparp. Originally published in the Journal of Medical Internet Research (https://www.jmir.org), 14.01.2022. This is an open-access article distributed under the terms of the Creative Commons Attribution License (https://creativecommons.org/licenses/by/4.0/), which permits unrestricted use, distribution, and reproduction in any medium, provided the original work, first published in the Journal of Medical Internet Research, is properly cited. The complete bibliographic information, a link to the original publication on https://www.jmir.org/, as well as this copyright and license information must be included. 